\title{
Meta-analysis of studies with genome sequencing in myelodysplastic syndrome treated with hypomethylating agents
}

\author{
Nikolay U. Tcvetkov, Olga S. Epifanovskaya, Yulia V. Rudnitskaya, Elena V. Morozova, Ivan S. Moiseev, Boris V. Afanasyev \\ R. Gorbacheva Memorial Institute of Children Oncology, Hematology and Transplantation, First Pavlov State Medical University \\ of St. Petersburg, St. Petersburg, Russia
}

Dr. Ivan S. Moiseev, R.Gorbacheva Memorial Institute of Children Oncology, Hematology and Transplantation, First Pavlov State Medical University of St. Petersburg, L. Tolstoy St 6-8, 197022, St. Petersburg, Russia
Phone: +7 (812) 3386259 (office); +7 (921) 7961951 (mob.) Fax: +7 (812) 3386263

E-mail:moisiv@mail.ru,nikolai.tcvetkov@yandex.ru

\section{Summary}

Myelodysplastic syndrome represents a heterogenous group of clonal diseases affecting the hematopoietic stem cells underlied by different somatic gene mutations and/or altered epigenetic regulation induced by the disturbed microenvironment, as well as changes in the immune surveillance system. In many patients, the MDS is preceded by a period of non-clonal or clonal cytopenias of a non-clear significance that are determined by age-associated somatic mutations and increased leukemia risks resulting into a higher cellular proliferation, inefficient clonal growth, suppression of normal hematopoiesis, and, finally, into altered differentiation, thus causing accumulation of blast forms and a risk of evolving into acute leukemia. Substantial data on prevalence and impact of mutations on the prognosis in myelodysplastic syndrome was accessed by multiple groups however the results of several published studies are controversial. Thus we have performed an unconventional meta-analysis by accessing resulting confidence intervals both by statistical means and by creating pulled database with available individual patient data. 12 studies with 1238 patients were analyzed. The observed prevalence of mutations was the subject to significant variability (95\%CI: ASXL1 13.6-29.8\%; DNMT3A 7.312.9\%; EZH2 2.4-7.0\%; U2AF1 3.7-13.8\%; TET2 14.232.5\%; RUNX1 3.9-13.7\%; TP53 4.7-15.2\%; SRSF2 7.128.1\%; RAS 2.2-15,1\%; SF3B1 4.4-12.2\%; CBL 0.1-8.9\%; None, $8.0-23.3 \% ; \mathrm{p}<0.0001)$. The analysis of response to hypomethylating agents revealed improved response in patients with TP53 (95\% CI 49-55\%, p=0.0003), TET2 (95\% CI 49-52\%, p=0.0001) and SRSF2 (95\% CI $48-54 \%, \mathrm{p}=0.0005)$ mutations; however the survival was worse in TP53 mutated patients (95\% CI 44-49\%, $\mathrm{p}=0.002)$ and better in SF3B1 mutated disease (95\% CI $47-54 \%, \mathrm{p}=0.01$ ). The magnitude of difference was less than previously reported. The study confirmed the previous reports on the impact of TP53, TET2 and SF3B1 mutations on prognosis. Further studies on the potential prognostic markers are required, especially in patients with absence of conventional mutations.

\section{Keywords}

Myelodysplastic syndrome, sequencing, mutations, treatment response, hypomethylating agents, metaanalysis.

\section{Introduction}

Myelodysplastic syndrome (MDS) is a heterogeneous group of clonal diseases with abnormalities in hematopoietic stem cells, which is based on somatic mutations of various genes and/or alterations in epigenetic regulation induced by disturbance of the microenvironment, as well as disturbances in the immune system of antitumor surveillance.
In many patients, the development of MDS is preceded by a period of non-clonal or clonal cytopenia of an unclear significance, which is induced by somatic mutations associated with age and an increased risk of leukemia. This results in increased proliferation, inefficiency of clonal hematopoiesis and suppression of normal hematopoiesis, and in advanced stages in an abrogation of differentiation, accumulation of blasts and the risk of transformation into acute leukemia. 
The incidence of MDS increases markedly with age and the disease is most prevalent in individuals who are white and male. It is conservatively estimated that $>10,000$ new cases of MDS occur annually, and that $\geq 60,000$ individuals with MDS currently reside in the United States [1].

Recent studies have provided consistent evidence of age-related hematopoietic clones (clonal hematopoiesis of indeterminate potential; CHIP) [2], driven by mutations of genes that are recurrently mutated in myeloid neoplasms and associated with increase in the risk of hematologic cancer. Although several issues remain to be clarified, targeted gene sequencing may be of potential value in the dissection between clonal myelodysplasia, nonclonal cytopenia, and clonal hematopoiesis arising upon aging or in the context of acquired marrow failure [3].

A distinctive feature of both MDS and a number of related diseases (MDS/myeloproliferative tumors, secondary acute myeloid leukemia) is an alteration in DNA methylation processes [4]. Currently, hypomethylating agents (HMA: 5-azacytidine and decitabine) are the only approved medications for the treatment of MDS $[5,6]$, but only $40-50 \%$ of patients respond to therapy [7]. Though there is relatively favorable cytogenetic subset of patients bearing $5 \mathrm{q}$ deletion with high initial response rate to lenalidomide, $35 \%$ of them will not respond to or do not tolerate the drug. Moreover, most of these patients will lose their response after a few years, requiring switching to HMA as one of further treatment options [8].

Existing prognostic factors regarding survival and the likelihood of response to therapy are based largely on the results of morphological and cytogenetic studies [9]. At the moment, their predictive power is insufficient to make a clinical decision regarding the rationale for therapy with HMA [10]. In connection with these problems, the search for biomarkers, which have prognostic significance with respect to survival and individual response to treatment, is ongoing.
The use of modern tools of genome research allowed taking a fresh look at the pathogenesis of MDS and related diseases. Genes involved in both methylation and other metabolic pathways are often mutated with MDS [11]. At the moment, a number of works have been published that analyze the mutational status of the main genes involved in the pathogenesis of MDS and their predictive value in the context of response to therapy and overall survival.

The main goal of our study was to compare the data on the frequency of mutations in different populations of patients with MDS. We also conducted a meta-analysis combining data from available studies to systematically assess the impact of mutation status on response and survival.

\section{Materials and methods}

\section{Data collection}

The electronic literature search was conducted in the PubMed and Cochrane database. Studies were selected if they enrolled patients with various forms of MDS, as well as MDS/myeloproliferative tumors, which underwent first-line therapy with hypomethylating agents. An additional prerequisite was the fact that these studies performed full-genomic or full-exome sequencing in order to identify somatic mutations having prognostic significance with respect to overall survival and/or response to therapy. The search terms were "myelodysplastic syndrome" "sequencing" "patients" and "azacitidine"/"decitabine". Only articles in English were included in the analysis (Fig. 1). According to these criteria, 12 original articles were selected (Table 1), from which primary data were extracted, which served as the basis for the combined database of this study. Mutation frequencies in the following genes were included in the combined database: ASXL1, DNMT3A, EZH2, U2AF1, TET2, RUNX1, TP53, SRSF2, RAS, SF3B1, CBL (Table 2).

\section{Table 1.The list of studies used for data analysis}

\begin{tabular}{|l|l|}
\hline Study (Ref. No. in parentheses) & Link \\
\hline Study 1 Korea, Jung SH et al. [15] & $\underline{\text { https://www.ncbi.nlm.nih.gov/pubmed/27419369 }}$ \\
\hline Study 2 Sweden, UK, Tobiasson M et al. [16] & $\underline{\text { https://www.ncbi.nlm.nih.gov/pubmed/269598855 }}$ \\
\hline Study 3 USA, Japan, Takahashi K et al. [17] & $\underline{\text { https://www.ncbi.nlm.nih.gov/pubmed/26871476 }}$ \\
\hline Study 4 USA, Bejar R et al. [10] & $\underline{\text { https://www.ncbi.nlm.nih.gov/pubmed/25224413 }}$ \\
\hline Study 5 USA, Brazil, Traina F et al. [13] & $\underline{\text { https://www.ncbi.nlm.nih.gov/pubmed/24045501 }}$ \\
\hline Study 6 France, Australia, USA, Japan, Merlevede J et al. [18] & $\underline{\text { https://www.ncbi.nlm.nih.gov/pubmed/26908133 }}$ \\
\hline Study 7 USA, Australia,UK, Sweden, Unnikrishnan A et al. [19] & $\underline{\text { https://www.ncbi.nlm.nih.gov/pubmed/28723562 }}$ \\
\hline Study 8 USA, Bejar R et al. [14] & $\underline{\text { https://www.ncbi.nlm.nih.gov/pubmed/22869879 }}$ \\
\hline Study 9 China, Chang CK et al. [20] & $\underline{\text { https://www.ncbi.nlm.nih.gov/pubmed/27984642 }}$ \\
\hline Study 10 USA, France, Italy, Meldi K et al. [21] & $\underline{\text { https://www.ncbi.nlm.nih.gov/pubmed/25822018 }}$ \\
\hline Study 11 USA, Welch JS et al. [11] & $\underline{\text { https://www.ncbi.nlm.nih.gov/pubmed/27959731 }}$ \\
\hline Study 12 Czech Republic, Polgarova K et al. [22] & $\underline{\text { https://www.ncbi.nlm.nih.gov/pubmed/29340104 }}$ \\
\hline
\end{tabular}


Table 2. Number of patients in whom the gene mutations were analyzed

\begin{tabular}{|l|l|}
\hline Genes & Number of patients \\
\hline ASXL1 & 938 \\
\hline DNMT3A & 921 \\
\hline EZH2 & 730 \\
\hline U2AF1 & 538 \\
\hline TET2 & 917 \\
\hline RUNX1 & 636 \\
\hline TP53 & 738 \\
\hline SRSF2 & 820 \\
\hline RAS & 735 \\
\hline SF3B1 & 896 \\
\hline CBL & 515 \\
\hline None (no mutations) & 551 \\
\hline Overall patients in all studies & 1238 \\
\hline
\end{tabular}

\section{Statistical analysis}

The meta-analysis included the studies with available individual mutational status along with response to HMA and/ or survival data. Based on this information a surrogate table was re-created with nominal variables. The interstudy difference in the prevalence of mutations as well as the response to therapy was analyzed with chi-square test based on the created surrogate tables. The survival variable was treated as logical and non-time dependent due to absence of individual time data. Confidence intervals for the incidence of mutations were calculated based on individual incidences in the studies with random effect model. The confidence intervals for response and survival were produced based on mixed models. The heterogeneity between studies was assessed with Cochran's $\mathrm{Q}$ test with $\mathrm{n}$ degrees of freedom. The studies with lees then ten patients per mutation were excluded from the heterogeneity analysis. The analysis was performed in SAS 9.3. The significance for all tests was set at 0.05.

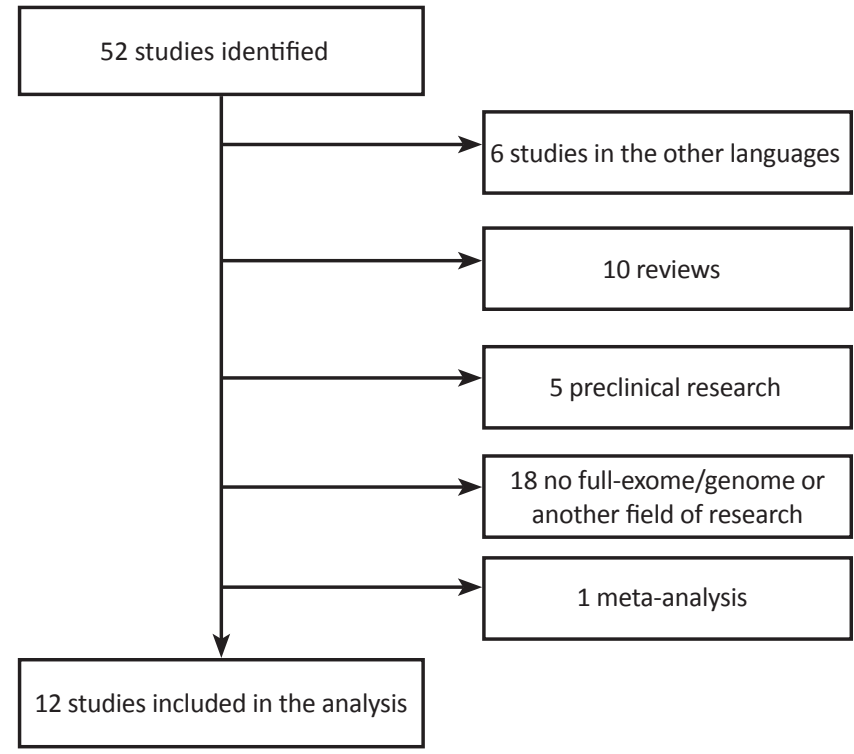

Figure 1. The diagram of the search process

\section{Results}

\section{Frequency of mutations in the studied population}

We observed a statistically significant difference in the frequencies of all the mutations studied, depending on the study population (for specific studies see Fig. 1). Mean frequency and $95 \% \mathrm{CI}$ for each mutation were as follows: ASXL1 22.5\% (13.6-29.8\%); DNMT3A 10.7\% (7.3-12.9\%); EZH2 5.3\% (2.4-7.0\%); U2AF1 9.5\% (3.7-13.8\%); TET2 21.3\% (14.232.5\%); RUNX1 9.1\% (3.9-13.7\%); TP53 9.4\% (4.7-15.2\%); SRSF2 $13.6 \%$ (7.1-28.1\%); RAS $4.9 \%$ (2.2-15.1\%); SF3B1 $12.0 \%$ (4.4-12.2\%); CBL 3.2\% (0.1-8.9\%); None $18.2 \%$ (8.0$23.3 \%) ; \mathrm{p}<0.0001$.

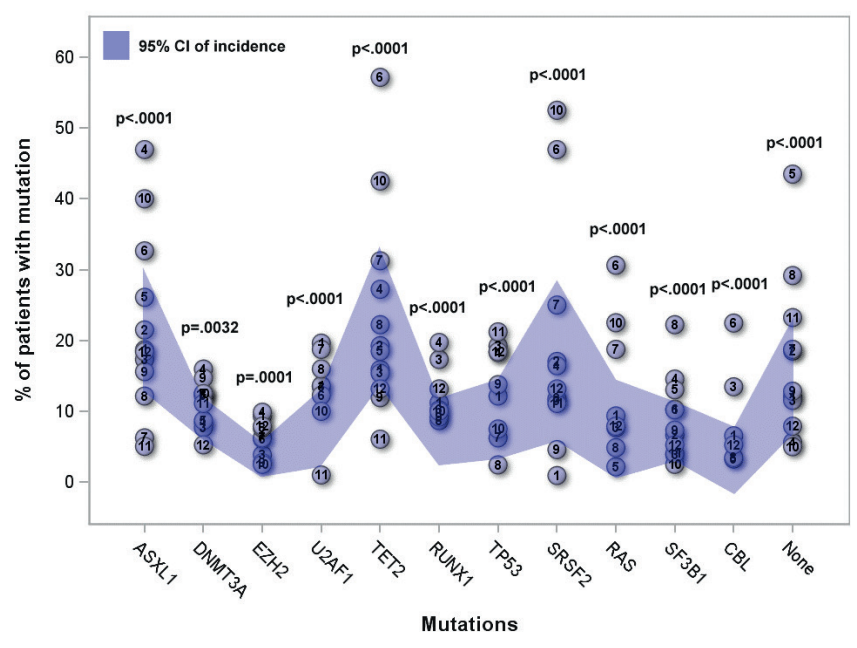

Figure 2. The inter-study differences for the incidence of mutations.

The dots represent incidence of mutations in different studies (see Table 1). The p-values are based on results of Hi-square testing of inter-study differences for distinct mutation frequencies. The blue band is the $95 \%$ confidence confidence interval for appropriate incidence rates

\section{Response to HMA and overall survival associated with presence of specific mutations} The simulation of common incidence table across studies demonstrated a statistically significant effect on the frequency of response to therapy for mutations in ASXL1, DNMT3A, TET2, RUNX1, TP53, SRSF2, SF3B1 genes and for patients without corresponding mutations (Fig. 3A, 4A). Mean response rates and $95 \% \mathrm{CI}$ for each mutation were: ASXL1 50.2\% (48.8-51.6\%); DNMT3A 50.4\% (48.3-52.5\%); EZH2 49.6\% (47.3-51.9\%); U2AF1 49.7\% (48.2-51.2\%); TET2 50.6\% (49.3-51.9\%); RUNX1 49.6\% (47.8-51.4\%); TP53 52.0\% (48.7-55.2\%); SRSF2 51.0\% (48.5-53.6\%); RAS $50.9 \%$ (36.9-64.7\%); SF3B1 50.3\% (48.5-52.1\%); CBL 49.0\% (44.9-53.1\%); None, 50.3\% (47.7-52.8\%).

A statistically significant effect on the level of survival for mutations in the genes ASXL1, DNMT3A, EZH2, U2AF1, TET2, RUNX1, TP53, SF3B1, CBL was revealed (Fig. 3B, 4B). Mean overall survival and 95\% CI for each mutation were: ASXL1 49.5\% (47.2-51.8\%); DNMT3A 48.7\% (45.6-51.9\%); EZH2 49.1\% (42.9-55.5\%); U2AF1 49.0\% (43.0-55.1\%); 
TET2 48.8\% (46.7-51.0\%); RUNX1 49.0\% (45.9-52.1\%); TP53 46.8\% (44.0-49.7\%); SRSF2 51.3\% (43.5-59.0\%); SF3B1 50.4\% (47.0-53.8\%); CBL 48.7\% (45.5-51.8); None, 52.6\% (10.0-91.7\%).

However, the magnitude of difference both in response and in survival was relatively modest. For example, the mean OS for DMT3A and TET2 were $48.7 \%$ and $48.8 \%$, respectively. Another example of close incidences of responses: $52.0 \%$ and $50.2 \%$ for patients with TP53 and TET 2 mutations, respectively.

Mutations in CBL, EZH2, U2AF1, RAS genes didn't produce any significant effect on response rate as well as there was no significant impact on survival observed for SRSF2 mutation and in patients without any corresponding mutations.

Fig. 4 contains the forest plot showing mean effects of different gene mutations upon drug response, overall survival, and appropriate confidence intervals.

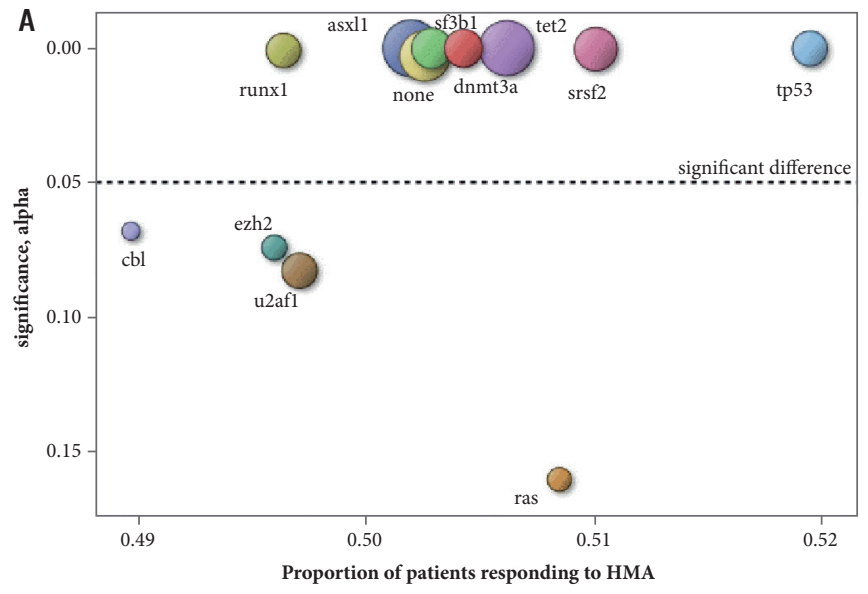

B

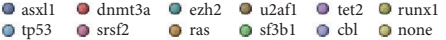

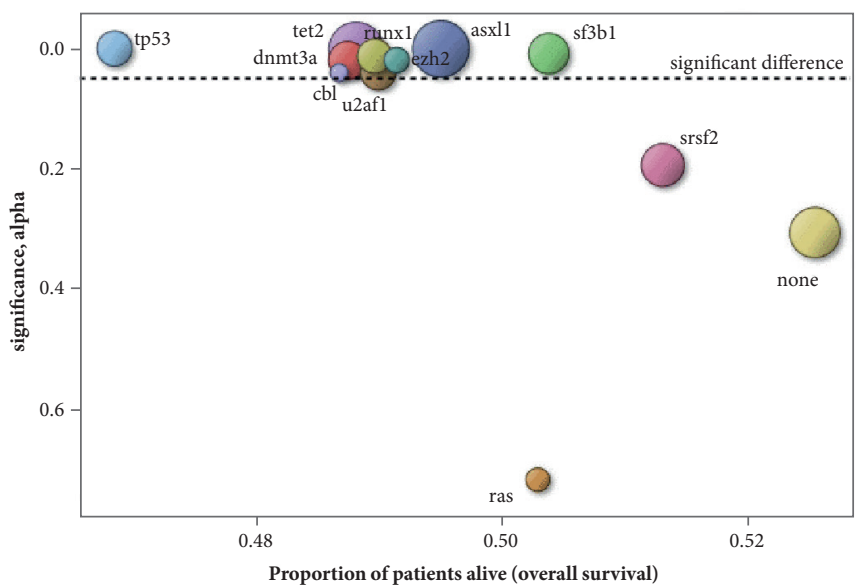

Figure 3. Frequency of response to the HMA therapy (A) and overall survival (B) for different mutations according to significance level.

A. Response to therapy. B. Overall survival. The $X$ axis is the proportion of patients responding (alive). The $Y$ axis is the significance of differences (alpha) compared to the other patients. The size of the bubble represents the incidence of the mutation.

\section{Discussion}

The identification of MDS patients with a high probability of response to HMA therapy remains an important and unresolved clinical task. From the available data, it is known that the presence of a number of somatic mutations can affect the response rates to therapy and the level of overall survival [12]. Mutations in the TET2, DNMT3A, TP53 genes were reported to be associated with a high probability of response to HMA $[13,14,15]$. At the same time, mutations in the EZH2 and TP53 genes are associated with a lower level of overall survival $[11,13]$. However these findings are not confirmed in the other studies $[11,15]$. Thus it is crucial to understand the reasons behind the variability of results.

In this study we summarized the results of 12 studies with whole exome/genome sequencing in MDS [10, 11, 13-22]. The main difference in this meta-analysis is the availability of individual patient data, thus we have not merged the confidence intervals and response rates, but re-created the interstudy database with mutations, response to therapy and survival. This approach allowed calculating very precise incidence of the mutations and confidence intervals on more than one thousand patients. The obvious weakness of the study is the absence of clinical risk stratification, longitudinal follow-up as well as duration and depth of the response.

One of the first important conclusions of this study is the significant heterogeneity in the incidence of mutations across studies. On the one hand, this might be due to heterogeneity in the age, gender, risk of the disease and high percentage of chronic myelomonocytic leukemia in several studies [18, 21]. On the other hand, the 2012 World Health Organization survey, revealed substantial difference in the incidence of blood cancer across the globe [23]. Thus the observed difference might be not only due to different inclusion criteria, but also due to variable prevalent biology of MDS in different ethnicities.

The other surprising finding was that despite significant differences in response and survival due to substantial number of patients in the analysis, the magnitude of difference was very modest almost for all of the mutations. The first studies identified significant impact of TET2 mutations on survival or response to therapy [24, 25], however after the accumulation of data in the other meta-analysis it was demonstrated that it is not a significant factor for response and survival [26]. The only exception found is the p53 mutation that has better primary response to therapy $[11,20]$, however it adversely affects survival compared to the other mutations, where despite lower response rates the survival was better. The study confirms the extremely negative impact of mutated p53 on prognosis that might not even be corrected by stem cell transplantation $[27,28]$. Another finding is improved survival in the SF3B1 mutation cohort, however as with other mutations the magnitude of the difference was modest compared to the previous studies [29].

Despite the trend towards a lower frequency of responses in the presence of RUNX1 mutation, these data require further detailed testing, and it should be emphasized that no mu- 


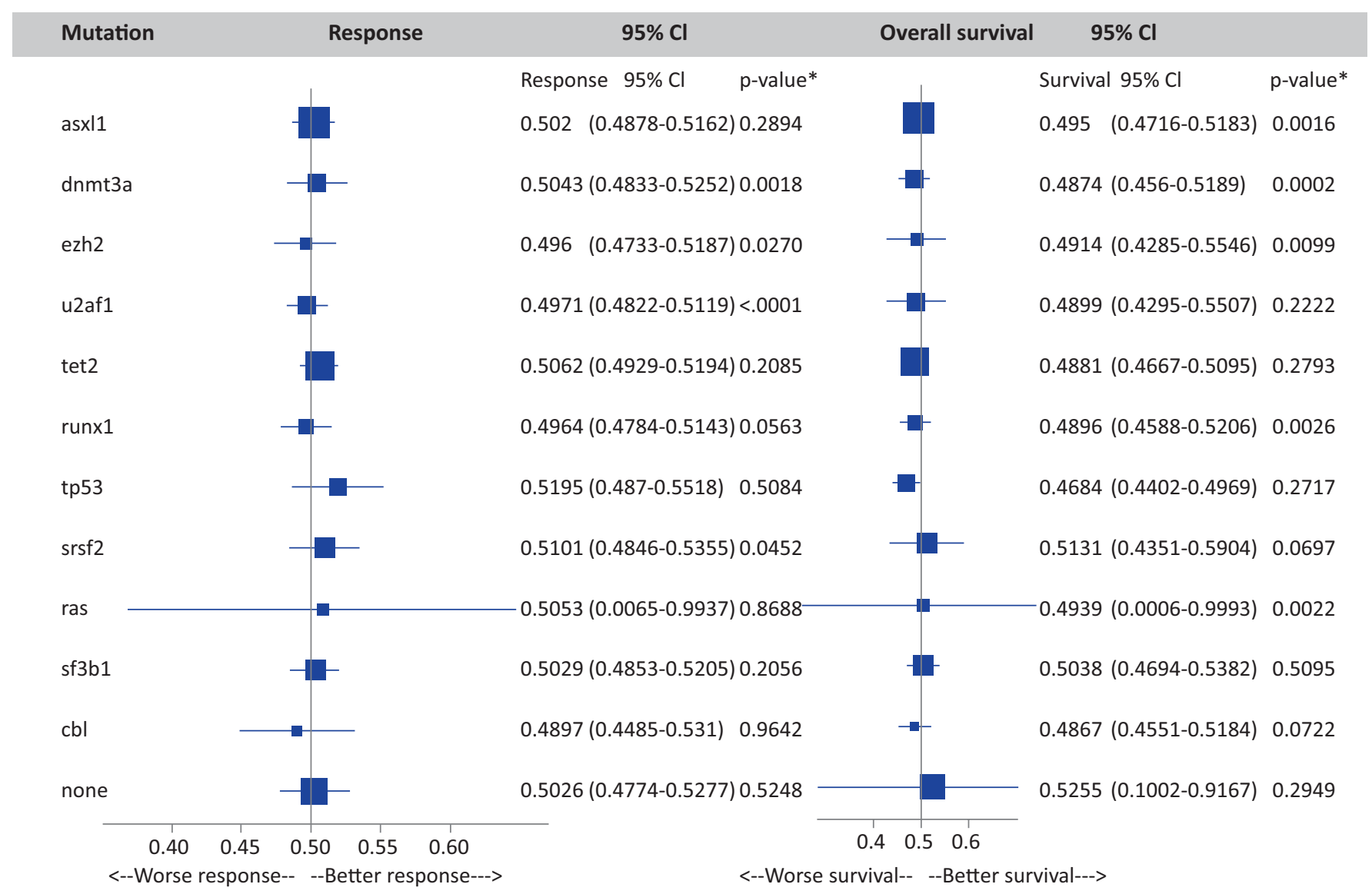

Figure 4. Forest plot of survival and response to HMA with $95 \%$ confidence intervals

Left panel shows response to hypomethylating agents, right panel, overall survival of patients. The confidence intervals are produced in the mixed modeling of the outcomes from individual studies weighted by the number of patients. The size of the marker represents the number of patients in the sub-groups. *The p-value is from the Cochran's $Q$ test for the heterogeneity between studies.

tation associated solely with the lack of response to HMA therapy is currently known, which would allow discussion of the inadvisability of this type of treatment when clinically indicated [11].

The observed confidence intervals of response to hypomethylating agents were comparable to the literature data of 40$50 \%[30,31]$, with little variance due to mutational status, which raises the question, whether the mutational status is a good prognostic factor. On the other hand the clinical risk scales have a very good predictive power in terms of survival [29]. And the drawback of this study, as well as in every meta-analysis, was the absence of individual clinical prognostic features, thus the correction for clinical co-variables could not be made. With these co-variables the results of the study could be significantly different. This demonstrates the need for international cooperation and joining both the sequencing and clinical data from different institutions. This type of activity could have provided further understanding of MDS and the approaches to treat it.

The interesting group in this study was patients without mutations determined with sequencing. Interestingly, though they had the response rate around median, the survival of these patients was much more heterogenic then in the known mutations groups. It demonstrates that this is also a heterogenic group with variable prognosis. The underlining mechanisms are still to be determined. The most promising approach is further elucidation of microenvironment disturbances and changes in miRNA signaling that lead to MDS [32].

In conclusion, the study demonstrated, though significant, but moderate impact of mutations in patients with MDS on response to HMA. Further cooperative studies with sharing the clinical and sequencing data are required to understand MDS pathophysiology and approaches to treatment.

\section{Acknowledgements}

This work was supported by Russian Science Foundation, grant № 17-75-20145. Authors confirm the absence of any conflicts of interests.

\section{References}

1. Ma X. Epidemiology of myelodysplastic syndromes. Am J Med. 2012;125(7 Suppl):S2-5.

2. Steensma DP, Bejar R, Jaiswal S, Lindsley RC, Sekeres MA, Hasserjian RP, Ebert BL. Clonal hematopoiesis of indeterminate potential and its distinction from myelodysplastic syndromes. Blood. 2015;126(1):9-16.

3. Malcovati L, Cazzola M. The shadowlands of MDS: idiopathic cytopenias of undetermined significance (ICUS) and clonal hematopoiesis of indeterminate potential (CHIP). He- 
matology Am Soc Hematol Educ Program 2015; 2015:299307.

4. Figueroa ME, Skrabanek L, Li Y, Jiemjit A, Fandy TE, Paietta E, Fernandez H, Tallman MS, Greally JM, Carraway H, Licht JD, Gore SD, Melnick A, Silverman LR. MDS and secondary AML display unique patterns and abundance of aberrant DNA methylation. Blood. 2009;114(16):3448-3458.

5. Kantarjian H, Issa JP, Rosenfeld CS, Bennett JM, Albitar M, DiPersio J, Klimek V, Slack J, de Castro C, Ravandi F, Helmer R $3^{\text {rd }}$, Shen L, Nimer SD, Leavitt R, Raza A, Saba H.Decitabine improves patient outcomes in myelodysplastic syndromes: results of a phase III randomized study. Cancer. 2006;106(8):1794-1803.

6. Garcia-Manero G, Shan J, Faderl S, Cortes J, Ravandi F, Borthakur G, Wierda WG, Pierce S, EsteyE, Liu J, Huang X, Kantarjian H.A prognostic score for patients with lower risk myelodysplastic syndrome. Leukemia. 2008;22(3):538-543.

7. Itzykson R, Kosmider O, Cluzeau T, Mansat-De Mas V, Dreyfus F, Beyne-Rauzy O, Quesnel B, Vey N, Gelsi-Boyer V, Raynaud S, Preudhomme C, Ades L, Fenaux P, Fontenay M; Groupe Francophone des Myelodysplasies (GFM). Impact of TET2 mutations on response rate to azacitidine in myelodysplastic syndromes and low blast count acute myeloid leukemias. Leukemia. 2011; 25(7):1147-1152.

8. Prebet T, Cluzeau T, Park S, Sekeres MA, Germing U, Ades L, Platzbecker U, Gotze K, Vey N, Oliva E, Sugrue MM, Bally C, Kelaidi C, Al Ali N, Fenaux P, Gore SD, Komrokji R. Outcome of patients treated for myelodysplastic syndromes with $5 \mathrm{q}$ deletion after failure of lenalidomide therapy. Oncotarget. 2017;8(47):81926-81935.

9. Zeidan AM, Smith BD, Komrokji RS, Gore SD. Prognostication in myelodysplastic syndromes: beyond the International Prognostic Scoring System (IPSS). Am J Med. 2013;126(4):e25.

10. Bejar R, Stevenson KE, Caughey BA, Abdel-Wahab O, Steensma DP, Galili N, Raza A, Kantarjian H, Levine RL, Neuberg D, Garcia-Manero G, Ebert BL. Validation of a prognostic model and the impact of mutations in patients with lower-risk myelodysplastic syndromes. J ClinOncol. 2012;30(27):3376-3382.

11. Welch JS, Petti AA, Miller CA, Fronick CC, O'Laughlin M, Fulton RS, Wilson RK, Baty JD, Duncavage EJ, Tandon B, Lee YS, Wartman LD, UyGL, Ghobadi A, Tomasson MH, Pusic I, Romee R, Fehniger TA, Stockerl-Goldstein KE, Vij R, Oh ST, Abboud CN, Cashen AF, Schroeder MA, Jacoby MA, Heath SE, Luber K, Janke MR, Hantel A, Khan N, Sukhanova MJ, Knoebel RW, Stock W, Graubert TA, Walter MJ, Westervelt P, Link DC, DiPersio JF, Ley TJ. TP53 and decitabine in acute myeloid leukemia and myelodysplastic syndromes. N Engl J Med. 2016; 375(21):2023-2036.

12. Montalban-Bravo G, Takahashi K, Patel K, Wang F, Xingzhi S, Nogueras GM, Huang X, Pierola AA, Jabbour E, Colla S, Gañan-Gomez I, Borthakur G, Daver N, Estrov Z, Kadia T, Pemmaraju N, Ravandi F, Bueso-Ramos C, Chamseddine A, Konopleva M, Zhang J, Kantarjian H, Futreal A, Garcia-Manero G. Impact of the number of mutations in survival and response outcomes to hypomethylating agents in pa- tients with myelodysplastic syndromes or myelodysplastic/ myeloproliferative neoplasms. Oncotarget. 2018;9(11):97149727.

13. Traina F, Visconte V, Elson P, Tabarroki A, Jankowska AM, Hasrouni E, Sugimoto Y, Szpurka H, Makishima H, O'Keefe CL, Sekeres MA, Advani AS, Kalaycio M, Copelan EA, Saunthararajah Y, Olalla Saad ST, Maciejewski JP, Tiu $\mathrm{RV}$. Impact of molecular mutations on treatment response to DNMT inhibitors in myelodysplasia and related neoplasms. Leukemia. 2014;28(1):78-87.

14. Bejar R, Lord A, Stevenson K, Bar-Natan M, Perez-Ladaga A, Zaneveld J, Wang H, Caughey B, Stojanov P, Getz G, Garcia-Manero G, Kantarjian H, Chen R, Stone RM, Neuberg D, Steensma DP, Ebert BL. TET2 mutations predict response to hypomethylating agents in myelodysplastic syndrome patients. Blood. 2014;124(17):2705-2712.

15. Jung SH, Kim YJ, Yim SH, Kim HJ, Kwon YR, Hur EH, Goo BK, Choi YS, Lee SH, Chung YJ, Lee JH. Somatic mutations predict outcomes of hypomethylating therapy in patients with myelodysplastic syndrome. Oncotarget. 2016;7(34):55264-55275.

16. Tobiasson M, McLornan DP, Karimi M, Dimitriou M, Jansson M, Ben Azenkoud A, Jädersten M, Lindberg G, Abdulkadir H, Kulasekararaj A, Ungerstedt J, Lennartsson A, Ekwall K, Mufti GJ, Hellström-Lindberg E. Mutations in histone modulators are associated with prolonged survival during azacitidine therapy. Oncotarget. 2016;7(16):22103-2215.

17. Takahashi K, Patel K, Bueso-Ramos C, Zhang J, Gumbs C, Jabbour E, Kadia T, Andreeff M, Konopleva M, DiNardo C, Daver N, Cortes J, Estrov Z, Futreal A, Kantarjian H, Garcia-Manero G. Clinical implications of TP53 mutations in myelodysplastic syndromes treated with hypomethylating agents. Oncotarget. 2016;7(12):14172-14187.

18. Merlevede J, Droin N, Qin T, Meldi K, Yoshida K, Morabito M, Chautard E, Auboeuf D, Fenaux P, Braun T, Itzykson R, de Botton S, Quesnel B, Commes T, Jourdan E, Vainchenker W, Bernard O, Pata-Merci N, Solier S, Gayevskiy V, Dinger ME, Cowley MJ, Selimoglu-Buet D, Meyer V, Artiguenave F, Deleuze JF, Preudhomme C, Stratton MR, Alexandrov LB, Padron E, Ogawa S, Koscielny S, Figueroa M, Solary E. Mutation allele burden remains unchanged in chronic myelomonocytic leukemia responding to hypomethylating agents. Nat Commun. 2016;7:10767.

19. Unnikrishnan A, Papaemmanuil E, Beck D, Deshpande NP, Verma A, Kumari A, Woll PS, Richards LA, Knezevic K, Chandrakanthan V, Thoms JAI, Tursky ML, Huang Y, Ali Z, Olivier J, Galbraith S, Kulasekararaj AG, Tobiasson M, Karimi M, Pellagatti A, Wilson SR, Lindeman R, Young B, Ramakrishna R, Arthur C, Stark R, Crispin P, Curnow J, Warburton P, Roncolato F, Boultwood J, Lynch K, Jacobsen SEW, Mufti GJ, Hellström-Lindberg E, Wilkins MR, MacKenzie KL, Wong JWH, Campbell PJ, Pimanda JE. Integrative genomics identifies the molecular basis of resistance to azacitidine therapy in myelodysplastic syndromes. Cell Rep. 2017;20(3):572-585.

20. Chang CK, Zhao YS, Xu F, Guo J, Zhang Z, He Q, Wu D, Wu LY, Su JY, Song LX, Xiao C, Li X. TP53 mutations predict 
decitabine-induced complete responses in patients with myelodysplastic syndromes. Br J Haematol. 2017;176(4):600608 .

21. Meldi K, Qin T, Buchi F, Droin N, Sotzen J, Micol JB, Selimoglu-Buet D, Masala E, Allione B, Gioia D, Poloni A, Lunghi M, Solary E, Abdel-Wahab O, Santini V, Figueroa ME. Specific molecular signatures predict decitabine response in chronic myelomonocytic leukemia. J Clin Invest. 2015;125(5):1857-1872.

22. Polgarova K, Vargova K, Kulvait V, Dusilkova N, Minarik L, Zemanova Z, Pesta M, Jonasova A, Stopka T. Somatic mutation dynamics in MDS patients treated with azacitidine indicate clonal selection in patients-responders. Oncotarget. 2017;8(67):111966-111978.

\section{GLOBOCAN 2012, IARC - 14.3.2018}

24. Kosmider O, Gelsi-Boyer V, Cheok M, Grabar S, Della-Valle V, Picard F, Viguié F, Quesnel B, Beyne-Rauzy O, Solary E, Vey N, Hunault-Berger M, Fenaux P, Mansat-De Mas V, Delabesse E, Guardiola P, Lacombe C, Vainchenker W, Preudhomme C, Dreyfus F, Bernard OA, Birnbaum D, Fontenay M, Groupe Francophone des Myélodysplasies. TET2 mutation is an independent favorable prognostic factor in myelodysplastic syndromes (MDSs). Blood. 2009; 114(15):3285-3291.

25. Smith AE, Mohamedali AM, Kulasekararaj A, Lim Z, Göken J, Lea NC, Przychodzen B, Mian SA, Nasser EE, Shooter C, Westwood NB, Strupp C, Gattermann N, Maciejewski JP, Germing U, Mufti GJ. Next-generation sequencing of the TET2 gene in 355 MDS and CMML patients reveals low-abundance mutant clones with early origins, but indicates no definite prognostic value. Blood. 2010; 116(19):3923-3932.

26. Lin Y, Lin Z, Cheng K, Fang Z, Li Z, Luo Y, Xu B. Prognostic role of TET2 deficiency in myelodysplastic syndromes: A meta-analysis. Oncotarget. 2017; 8(26): 43295-43305.

27. Papaemmanuil E, Gerstung M, Bullinger L, Gaidzik VI, Paschka P, Roberts ND, Potter NE, Heuser M, Thol F, Bolli N, Gundem G, Van Loo P, Martincorena I, Ganly P, Mudie L, McLaren S, O'Meara S, Raine K, Jones DR, Teague JW, Butler AP, Greaves MF, Ganser A, Döhner K, Schlenk RF, Döhner $\mathrm{H}$, Campbell PJ. Genomic classification and prognosis in acute myeloid leukemia. N Engl J Med. 2016; 374(23):22092221.

28. Kröger N, Iacobelli S, Franke GN, Platzbecker U, Uddin R, Hübel K, Scheid C, Weber T, Robin M, Stelljes M, Afanasyev B, Heim D, Deliliers GL, Onida F, Dreger P, Pini M, Guidi S, Volin L, Günther A, Bethge W, Poiré X, Kobbe G, van Os M, Brand R, de Witte T. Dose-reduced versus standard conditioning followed by allogeneic stem-cell transplantation for patients with myelodysplastic syndrome: a prospective randomized Phase III Study of the EBMT (RICMAC Trial). J ClinOncol. 2017;35(19):2157-2164.

29. Greenberg PL1, Tuechler H, Schanz J, Sanz G, Garcia-Manero G, Sole F, Bennett JM, Bowen D, Fenaux P, Dreyfus F, Kantarjian H, Kuendgen A, Levis A, Malcovati L, Cazzola M, Cermak J, Fonatsch C, Le Beau MM, Slovak ML, Krieger O, Luebbert M, Maciejewski J, Magalhaes SM,
Miyazaki Y, Pfeilstöcker M, Sekeres M, Sperr WR, Stauder R, Tauro S, Valent P, Vallespi T, van de Loosdrecht AA, Germing $\mathrm{U}$, Haase D. Revised international prognostic scoring system for myelodysplastic syndromes. Blood. 2012;120(12):24542465.

30. Sekeres MA. Epidemiology, natural history, and practice patterns of patients with myelodysplastic syndromes in 2010 . J Natl Compr Canc Netw. 2011;9(1):57-63.

31. Zeidan AM. Risk stratification in therapy-related myelodysplastic syndromes. Oncotarget. 2017;8(46):80103-80104.

32. Sokol L, Estes M, Williams AH, Ozawa Y, Volinia S, Liu CG, Croce CM, List AF. Myelodysplastic syndromes (MDS) display a risk and senescence-dependent microRNA (miRNA) signature. Blood 2006 108:2630. 


\title{
Мета-анализ исследований с помощью геномного секвенирования пациентов с миелодиспластическим синдромом, получающих терапию гипометилирующими агентами
}

\author{
Николай Ю. Цветков, Ольга С. Епифановская, Юлия В. Рудницкая, Елена В. Морозова, Иван С. Моисеев, \\ Борис В. Афанасьев \\ НИИ детской онкологии, гематологии и трансплантологии им. Р. М. Горбачевой, Первый Санкт-Петербургский \\ государственный медицинский университет им. И. П. Павлова, Санкт-Петербург, Российская Федерация
}

\section{Резюме}

Миелодиспластический синдром (МДС) представляет собой гетерогенную группу клональных заболеваний с поражением гемопоэтической стволовой клетки крови, в основе которых лежат соматические мутации различных генов и/или эпигенетической регуляции, индуцированной нарушением микроокружения, а также нарушения в иммунной системе противоопухолевого надзора. У многих пациентов развитию МДС предшествует период неклональных или клональных цитопений неясного значения, что обусловлено появлением соматических мутаций, ассоциированных с возрастом и повышенной вероятностью развития лейкоза. Результатом этого является увеличение пролиферации, нарастанием неэффективности клонального и угнетением нормального гемопоэза и, на конечных этапах, нарушением дифференцировки, что приводит к накоплению бластов и риску трансформации в острый лейкоз. Значительные данные о распространенности и воздействии мутаций на прогноз при миелодиспластическом синдроме были получены различными группами, однако результаты во многих случаях противоречивы. В связи с этим мы провели метаанализ с объединением доступных данных. Было проанализировано 12 исследований с общим количеством пациентов - 1238. Наблюдалась значи- тельная вариабельность в распространенности мутаций между исследованиями (95\% ДИ: ASXL1 13,629,8\%, DNMT3A 7,3-12,9\%, EZH2 2,4-7,0\%, U2AF1 3,7-13,8\%, TET2 14,2-32,5\%, RUNX1 3,9-13,7\%, TP53 4,7-15,2\%, SRSF2 7,1-28,1\%, RAS 2,2-15,1\%, SF3B1 4,4$12,2 \%$, CBL 0,1-8,9\%, нет 8,0-23,3\%, p<0,0001). Анализ эффективности гипометилирующих препаратов показал более высокий ответ у пациентов с мутациями TP53 (95\% CI 49-55\%, p=0.0003), TET2 (95\% CI 49$52 \%, \mathrm{p}=0.0001$ ) и SRSF2 (95\% CI 48-54\%, $\mathrm{p}=0.0005$ ), однако выживаемость была хуже у пациентов смутированным ТР53 (95\% СI 44-49\%, p=0.002) и лучше в случае мутации SF3B1 (95\% CI 47-54\%, p=0.01). Величина различий была меньше, чем сообщалось ранее. Исследование подтвердило предыдущие сообщения о влиянии мутации p53, tet2 и sf3b1 на прогноз. Дальнейшие исследования потенциальных прогностических маркеров необходимы при вариантах МДС без общепризнанных мутаций.

\section{Ключевые слова}

Миелодиспластический синдром, секвенирование, мутации, ответ на терапию, мета-анализ, гипометилирующие препараты. 